\title{
PRELIMINARY PHYTOCHEMICAL SCREENING AND ANTIMICROBIAL ACTIVITY OF DRIED FLOWERS OF ADENIUM OBESUM
}

\author{
SIREESHA KALVA*, RAGHUNANDAN N. \\ *Sri Venkateshwara College of Pharmacy, Osmania University, Madhapur, Hyderabad, Balaji Institute of Pharmaceutical Sciences, \\ Kakatiya University, Narsampet, Warangal \\ Email: sireesha.kalva@gmail.com
}

Received: 15 Nov 2018, Revised and Accepted: 20 Feb 2019

\begin{abstract}
Objective: To estimate the antimicrobial activity of methanolic extract of Adenium obesum (family Apocyanaceae) in association with phytochemical analysis.

Methods: The methanolic extract of the flowers of Adenium obesum was prepared and investigated for phytochemical constituents using standard methods. Antimicrobial activity of methanolic extract Adenium obesum has been carried out against one gram-positive bacteria Staphylococcus aureus and one gram-negative bacteria Escherichia coli and the antifungal activity of the plant extract was evaluated on Candida albicans species. The testing was done by the disc diffusion method to visualize the zone of inhibition of methanolic extract was compared with that of standard drug i.e., Ciprofloxacin for antibacterial activity and Fluconazole for antifungal activity. The minimum inhibition concentration was determined by micro dilution method (cup-plate method).
\end{abstract}

Results: The present investigation shows the phytochemical analysis confirmed the presence of alkaloids, saponin glycosides, flavonoids, phenols, proteins and amino acids, cardiac glycosides, steroids, tannin, and phenolic compounds. The anti-microbial activity of the methanolic extract of the plant showed significant results against all the three of the test organisms in compare to the standard drugs.

Conclusion: The present study concluded that methanolic extract of the flowers of adenium obesum proved the existence of phytochemical constituents. The methanolic extract of the was found to possess promising antimicrobial activity when compared with the standards and it can be useful for the development of antibiotics.

Keywords: Adenium obesum, Antimicrobial, Minimum inhibition concentration

(C) 2019 The Authors. Published by Innovare Academic Sciences Pvt Ltd. This is an open-access article under the CC BY license (http://creativecommons.org/licenses/by/4.0/) DOI: http://dx.doi.org/10.22159/ijcpr.2019v11i2.33022

\section{INTRODUCTION}

For a long period of time, there are many naturally occurring materials which are having biologically active substance and show biological activity for the health of human beings and they have great potential for producing new drugs. In plant chemotherapy, the use of naturally occurring antimicrobial substance is gaining more importance and have higher significant value [1]. Medicinal plants have an important role for the health of individuals and communities. These plants have a great medicinal value that lies in various chemical substances which produce physiological action on the human body. Medicinal plants contains many chemical compounds such as alkaloids, flavonoids, glycosides, saponinis, resins, oleoresins, sesquiterpenes, phenolic compounds, fats and oils [2]. According to WHO medicinal plants are used in order to the therapeutic purpose and can be used as processing the synthesis, semi-synthetic chemical drugs [3].

About $80 \%$ of the world population depending on the herbal-based alternative system of medicine like Ayurveda. Despite the major advances in the modern medicine, the development of new drugs from natural products is still considered important. The evaluation of various plant products according to their traditional uses and medicinal value based on their therapeutic efficacy leads to the discovery of newer and recent drugs for treating various aliments [4] Antibiotics resistance is a growing problem. The wide spirit and indiscriminate uses of antibacterial agents resulted in the development of resistance among many virulently pathogenic bacteria species. Many of the currently used antibacterials are associated with adverse effects such as toxicity, hypersensitivity, immune suppression, and tissue residues posing a public health hazard [5].

Adenium obesum is a succulent plant commonly known as desert rose belongs to the dogbane family Apocyanacea is a native from Africa such as Ethiopia, Kenya, Senegal, Somalia, Sudan, also found in
Oman, Saudi Arabia and Yemen as wild plant. It is one of the popular ornamental plants cultivated in many humid, tropical countries for decades such as India, Philippines and Thailand [6-11].

Adenium obesum is a beautiful deciduous pachycaul shrub with an attractive swollen trunk and fleshy smooth, greyish-green to brown colored, irregular-spaced branches that make it a unique and attractive for bonsai. It produces lovely, variously colored star-shaped flowers, but without fragrance. Terminal clusters of flowers are formed during the entire year [12]. Adenium obesum is an important medicinal plant which shows a wide range of biological activities. The pant exhibits anticancer, antiviral, antibacterial, trypanocidal, acarcidal, molluscicidal, antioxidant and piscicidal activities [13].

So the target of this present study is to identify the phytochemical components of Adenium obesum and to determine the antimicrobial effects of the dried flower extract on E. coli, S. aureus and Candida albicans.

\section{MATERIALS AND METHODS}

\section{Collection of plant materials}

The flowers of Adenium obesum were collected from Tirumala Hills, Tirupathi, Andhra Pradesh during the month of July-Aug 2015. The authentication was done by S. V University, Botony department, Tirupati bearing a voucher no.1242.

\section{Preparation of extract of adenium obesum flowers}

The flowers obtained were dried under shade. The dried flowers were crushed, placed in a closed vessel. To the powder required quantities of methanol was added into the containers and allowed to stand for $7 \mathrm{~d}$ with occasionally shaking. The liquid was strained off, the solid residue was pressed, clarified by filtration and then 
subjected to evaporation. The percent yield of methanolic extract was then calculated out.

\section{Preparation of extract/drug stock solution}

The stock solution ofAdenium obesum flower extract was prepared on each occasion by careful weighing and dissolving in a suitable volume of Dimethylsulphoxide (DMSO) to get a concentration of 100 $\mathrm{mg} / \mathrm{ml}$. A tablet of ciprofloxacin was dissolved in an appropriate volume of water to get $5 \mathrm{mg} / \mathrm{ml}$ of stock solution.

\section{Phytochemical screening}

Phytochemicals screening were done using the standard method. All the experiment has been repeated in triplicate for final confirmation of the result.

1. Test for Saponins: To $1 \mathrm{ml}$ of aqueous extract was added to few volume of distilled water in a test tube. The solution was shaken vigorously and observed for a stable persistent froth for $20 \mathrm{~min}$.

2. Test for alkaloids: Two methods were used to test for alkaloids. First, evaporate $20 \mathrm{ml}$ of ethanol extract, the dry residue dissolved in $5 \mathrm{ml}$ of HCL $(2 \mathrm{~N})$ and filtered. A few drops of Mayer's reagent and Wagner was added, and the presence of precipitate indicates the alkaloids.

Second, 3 to $15 \mathrm{ml}$ of the aqueous extract was added $2 \mathrm{ml}$ of $\mathrm{NH}_{4} \mathrm{OH}$ a $10 \%$. The alkaloid was extracted 3 times with $10 \mathrm{ml}$ chloroform. The chloroform layer was washed 3 times with $2 \mathrm{ml}$ of HCL (10\%). This was divided into two portions. Mayer's reagent was added to one portion and Wagner's reagent to the other. The formation of a brown or white precipitate was regarded as positive for the presence of alkaloids

3. Test for sterols and steroids: Extracts were treated with chloroform and filtered. The filtrates were treated with few drops of Conc. Sulphuric acid, shaken and allowed to stand. Appearance of golden yellow color indicates the presence of triterpene.

4. Test for the phenolic compounds: Flavonoids: The ethanol extract $5 \mathrm{ml}$ was added to a concentrated sulphuric acid $\left(\mathrm{H}_{2} \mathrm{SO}_{4}\right)(1$ $\mathrm{ml}$ ) and $0.5 \mathrm{mg}$ of $\mathrm{Mg}$. A pink or red coloration that disappears on standing $3 \mathrm{~min}$. indicates the presence of flavonoids.

5. Tannins: Two methods were used to test for tannins. First, about $1 \mathrm{ml}$ of the ethanol extract was added in $2 \mathrm{ml}$ of water in a test tube. 2 to 3 drops of diluted ferric chloride $\left(\mathrm{Fecl}_{3}\right)$ solution was added and observed for green to blue-green or blue-black coloration. Second, 2 $\mathrm{ml}$ of the aqueous extract was added to $2 \mathrm{ml}$ of water, 1 to 2 drops of diluted ferric chloride $\left(\mathrm{Fecl}_{3}\right)$ solution were added. A dark green or blue-green coloration indicates the presence of tannins.

6. Test for Glycosides: $2 \mathrm{ml}$ of concentrated H2SO4was added carefully and shaken gently. A reddish brown color indicated the presence of steroidal ring i. an aglycone portion of the glycoside $[14,15]$.

\section{Culture media}

The media employed for the culture was solid agar media.

\section{Microbial strains}

Three bacterial strains [Staphylococcus aureus, Escherichiacoli] and one fungi Candida albicans were used. Stains were obtained from National Institute of Nutrition (NIN), Hyderabad.

\section{Sterilization of materials}

The petri dishes and pipettes packed into metal canisters were appropriately sterilized in the hot air oven at $170{ }^{\circ} \mathrm{c}$ for $1 \mathrm{hr}$ at each occasion. A solution of the extract and culture media were autoclaved at $121^{\circ} \mathrm{C}$ for $15 \mathrm{~min}$.

\section{Antibacterial activity}

The antimicrobial activity of the methanolic extract of the plant was assayed by agar-well diffusion method as described in NCCLS (1993) [16] Petri plates containing $20 \mathrm{ml}$ nutrient agar medium was seeded with bacterial strains. Wells of approximately $10 \mathrm{~mm}$ was bored using a well cutter. Plant extract was prepared in DMSO $(1 \mathrm{mg} / \mathrm{ml})$. the plant extract of 25,50 and $100 \mu$ l concentration were added. Ciprofloxacin

(20 $\mu \mathrm{l})$ and DMSO $100 \mu \mathrm{l}$ were used as positive and negative controls respectively.

The plates were then incubated at $37{ }^{\circ} \mathrm{c}$ for $24 \mathrm{~h}$. The antimicrobials present in the plant extract are allowed to diffuse into the medium and interact with the test organisms in the freshly seeded plate. The diameter of the zone of inhibition was measured in millimeters after $24 \mathrm{~h}$.

\section{Antifungal activity}

The dextrose agar plates were prepared and inoculated with a fungal culture. Wells of approximately $10 \mathrm{~mm}$ was bored using a well cutter and samples of different concentration were added. The zone of inhibition was measured in millimeters after overnight incubation and compared with that of standard antifungal (Fluconazole10 $\mu \mathrm{l}$ ). Which was used as positive control and DMSO (10\%) as a negative control [17].

\section{RESULTS}

The present systematic examination shows the phytochemical analysis, antimicrobial activity of the methanolic extract of the flowers of Adenium obesium. The \% of the extraction of methanol as $17.09 \%$.

\section{Phytochemical analysis}

The phytochemical analysis with the methanolic extracts of the dried flowers of plant Adenium obesum showed the presence of alkaloids, saponin, sterols, terpeniods, protein and amino acids, tannins, carbohydrates.

\section{Antimicrobial activity}

Generally, Methanolic extract of Adenium obesum (MEAO) plant extracts are rich in antimicrobial compounds. The in vitro antimicrobial study of the methanolic extract of flowers of Adenium obesum showed antimicrobial activity against most of the test organisms.

Table 1: Antimicrobial activity of methanolic extract of dried flowers of Adenium obesum

\begin{tabular}{llll}
\hline \multirow{2}{*}{$\begin{array}{l}\text { Name of the compound } \\
\text { and concentration }\end{array}$} & \multicolumn{2}{l}{ Antibacterial activity diameter inhibition zone (mm) } & Antifungal activity diameter of inhibition zone (mm) \\
\cline { 2 - 4 } & Staph. aureus & E. coli & C. albicans \\
\hline MEAO $(25 \mu \mathrm{l})$ & 14 & 9.7 & 8.05 \\
MEAO $(50 \mu \mathrm{l})$ & 19.65 & 11.63 & 17.87 \\
MEAO $(100 \mu \mathrm{l})^{*}$ & 24.54 & 21.92 & 23.4 \\
Standard Drug & 38 & 40 & $-\cdots$ \\
Ciprofloxacin $(20 \mu \mathrm{l})$ & & & 33.5 \\
Standard Drug & ------ & & \\
Fluconazole $(20 \mu \mathrm{l})$ & & & \\
\hline
\end{tabular}




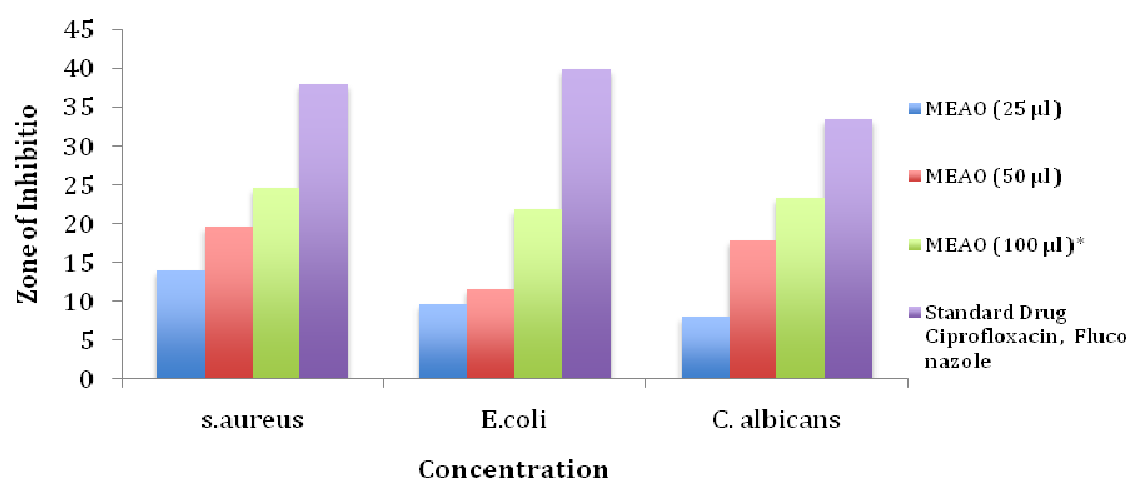

Fig. 1: Zone of inhibition vs concentration

\section{DISCUSSION}

As resistance to antibiotics is increasing the alternative system of medicine viz. Ayurveda, Siddha, and traditional Chinese medicine have become more popular in recent years. Antimicrobial activity of dried flowers of Adenium obesum has been evaluated.

The phytochemical constituents of plants such as tannins, alkaloids, flavonoids, phenolic compounds, and several other aromatic compounds are secondary metabolites which can be used in achieving a defense mechanism against plundering by many microorganisms.

The methanolic extract of the adenium obesum has shown significant antibacterial action against gram-positive bacteria S. aureus and gram-negative bacteria E. coli, and antifungal activity against C. albicans and compared with the standard drugs Ciprofloxacin and fluconazole.

The explanation of antimicrobial activity against Gram-positive and Gram-negative bacteria andante Fungal strains may be an indication of something presence of broad-spectrum antibiotic compounds in the extracts which is shown in fig. 1 . The $100 \mu$ l concentration of dried flowers of Adenium obesum has an influencing antimicrobial activity.

\section{CONCLUSION}

The results confirms the it has the significant antimicrobial activity of the methanolic extract of Adenium obesum. The plant extracts have great potential as antimicrobial compound against diseasecausing microorganisms.

\section{ACKNOWLEDGMENT}

I am very thankful to my college principal and management of Sri Venkateshwara College of Pharmacy for their support.

\section{CONFLICTS OF INTERESTS}

Declared none

\section{REFERENCES}

1. Nada KK, Zainab AGC. Antimicrobial activity of different aqueous lemon extracts. J Appl Pharm Sci 2013;3:74-8.

2. Maruti J, Dhanavade CB, Jalkute JS, Ghosh Kailash DS. Study antimicrobial activity of lemon. $\mathrm{Br} \mathrm{J}$ Pharmacol Toxicol 2011;2:119-22.

3. Behboud J, Amirreza K. Antibacterial activities methanol of extract and lemongrass essence on pathogenic bacteria. World Appl Sci J 2013;28:1796-801.

4. Brahma Chari UN. Herbal remedy. Curr Sci 2001;81:15-6.

5. Zitterl Eglseer K, Sosa S, Jurenitsch J, Tubaro A, Franz C. Antiedematous activities of the main triterpendiol esters of marigold. J Ethnopharmacol 1997;57:139-44.

6. Arbonnier M. Trees, shrubs and lianas of West African dry zones. Editions Quae; 2004.

7. Oyen LP. Adenium obesum (Forssk.) Roem and schult. Plant Resources Trop Africa 2008;11:46-9.

8. Win NK, Back CG, Kim YH, Jung HY. Desert rose witches' broom disease associated with 'Candidatus Phytoplasmaaurantifolia'. J Gen Plant Pathol 2012;78:73-6.

9. Rowley GD. Caudiciform and pachycaul succulents: pachycauls, bottle-, barrel-and elephant-trees and their kin, a collector's miscellany. Mill Valley: Calif., Strawberry Press; 1987. p. xiii, 282p.illus.

10. Mclaughlin J, Garofalo J. The desert rose, Adenium obesum: nursery production. Fact sheet; 2002.

11. Mclaughlin J, Garofalo J. The desert rose, Adenium obesum: nursery production. Fact sheet; 2002.

12. Paul D, Biswas K, Sinha SN. Biological activities of adenium obesum (Forssk.) roem and schult: a concise review. Malaya J Biosci 2015;2:214-21.

13. Koehn FE, Carter GT. The evolving role of natural products in drug discovery. Nat Rev Drug Discovery 2014;2:379-86.

14. http://www.businessdictionary.com/definition/pathogens.ht $\mathrm{ml}$ [Last accessed on 05 Oct 2018]

15. Parta AK. Dietary phytochemicals. Publisher spirzyeer; 2008. p. 301-6.

16. http://www.businessdictionary.com/definition/pathogens.ht $\mathrm{ml}$ [Last accessed on 05 Oct 2018] 